\title{
Bộ công cụ i2Metrix đắt hàng
}

Tạp chí Tia Sáng - Diễn đàn của trí thưc Việt Nam

Đổi mới sáng tạo

30/o6/2014 16:26-

Sau thời gian điều tra, phỏng vấn và cho ra kết quả năng lực đổi mới-sáng tạo-cạnh tranh của 19 doanh nghiệp Việt Nam, đến nay bộ công cụ i2Metrix đã được nhiều doanh nghiệp quan tâm và tiến hành đo.

Điểm đặc biệt, bộ công cụ i2Metrix không chỉ ứng dụng được cho các doanh nghiệp sản xuất lớn, mà ngay cả những cơ sở nhỏ, đơn vị kinh doanh đặc sản làng nghề cũng hoàn toàn có thể áp dụng các tiêu chí của bộ đo này để đánh giá năng lực đổi mới sáng tạo của mình.

Mới đây nhất, bên cạnh công ty cổ phần nhựa Rạng Đông, những doanh nghiệp như: Cơ sở chế biến thực phẩm Năm Thụy; cơ sở thu mua chế biến hàng thủy sản Tiến Hải; công ty cồ phần rượu Phú Lễ là những doanh nghiệp đã dùng bộ công cụ i2Metrix thực hiện việc đo lường, khảo sát.

Đáng chú ý, trong những doanh nghiệp trên thì cơ sở chế biến thực phẩm Năm Thụy; cơ sở thu mua chế biến hàng thủy sản Tiến Hải là những cơ sở đặc sản làng nghề của tỉnh Trà Vinh. Còn công ty cồ phần rượu Phú Lễ cũng là một đặc sản nổi tiếng của tỉnh Bến Tre.

Việc bộ công cụ i2Metrix tiến hành đo lường ở những doanh nghiệp đặc sản địa phương này cho thấy, đổi mới sáng tạo không chỉ gói gọn trong những doanh nghiệp lớn, mà càng ở những doanh nghiệp nhỏ, doanh nghiệp địa phương. Ở những doanh nghiệp này, tính cấp thiết của đổi mới sáng tạo càng càng trở nên quan trọng để họ tồn tại và mở rộng thị trường, đa dạng sản phẩm...

Dự kiến trong thời gian tới, bộ công cụ i2Metrix sẽ làm việc và tiến hành đo lường tại công ty Bóng đèn phích nước Rạng Đông và Tổng công ty viễn thông quân đội Viettel.Tính cho đến thời điểm hiện tại, bộ công cụ i2Metrix đã tiến hành đo lường, khảo sát 25 doanh nghiệp trền nhiều các lĩnh vực khác nhau của nền kinh tế.

i2Metrix là bộ chỉ số đo lường năng lực đổi mới-sáng tạo-cạnh tranh của doanh nghiệp do $\mathrm{BSA}$ và Công ty nghiên cứu kinh tế và tư vấn kinh doanh Dan Houtte, Vuong \& Partners Ltd (DHVP) cộng tác phát triển, cung cấp phương tiện định lượng để kiểm đếm quy mô nguồn lực sáng tạo, hiệu suất sử dụng và gợi ý giải pháp gia tăng 
hiệu quả khai thác nguồn lực này.

i2Metrix xác định năng lực đổi mới-sáng tạo của doanh nghiệp qua 10 kích thước. Độ lớn của từng kích thước tính bằng trung bình cộng giá trị các chỉ tiêu của kích thước đó. Các giá trị này được cho theo thang điểm từ 1 tới 10. Điểm cao hơn khi hiện trạng hoạt động đổi mới-sáng tạo của doanh nghiệp gần hơn với mong muốn hay kỳ vọng của người đánh giá. Để đảm bảo tính khách quan và giảm thiều các sai số đánh giá, người đánh giá gồm: (i) nhóm nghiên cứu BSA-DHVP, (ii) doanh nghiệp tự đánh giá; (iii) đại diện giới truyền thông; (iv) chuyên gia; và (v) đại diện người tiêu dùng. Điểm số cho từng chỉ tiêu cụ thể sẽ là giá trị trung bình của điểm số được cho bởi 05 nguồn này.

Các kích thước và chỉ tiêu đo lường cung cấp phương tiện để doanh nghiệp hình dung trực quan về hiện trạng năng lực đồi mới-sáng tạo của chính mình. Từ đó, định hướng và giải pháp cải thiện, tăng cường sức cạnh tranh được xây dựng với sự phân bổ nguồn lực hợp lý hơn. Từng chỉ tiêu định lượng sẽ là những tiêu chí rõ ràng để doanh nghiệp đối chiếu và xác định vị thế với đối thủ cạnh tranh, trong ngành và trên toàn thị trường.

Với những người làm chính sách và nghiên cứu, bộ dữ liệu i2Metrix cung cấp bằng chứng thực nghiệm và chỉ rõ những nội dung cần ưu tiên trợng điềm về nguồn lực, chính sách và giải pháp trong thúc đẩy, hổ trợ đổi mới-sáng tạo. Trên thị trường, các nhà đầu tư có tín hiệu để nhận biết tiềm năng phát triển trong tương lai của doanh nghiệp. Công chúng tiêu dùng có thêm thông số tin cậy để lựa chọn hàng hóa và dịch vụ cũng như tăng cường hiểu biết một cách trực quan và sinh động về lao động đổi mới-sáng tạo vốn mang tính trừu tượng cao.

Tags: 
